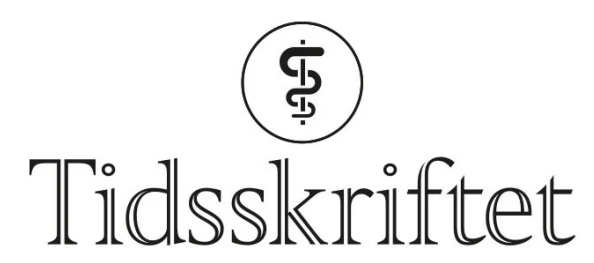

DEN NORSKE LEGEFORENING

\title{
Brannskader hos barn i Bergen
}

\author{
ORIGINALARTIKKEL
}

\section{CHRISTINA BRUDVIK}

Email: christina.brudvik@kir.uib.no

Institutt for kirurgiske fag

Universitetet i Bergen

Bergen Legevakt

Postboks 4500

5838 Bergen

\section{ELI LEIRDAL HOEM}

Helsebanken legekontor

$\emptyset$ ystese

\section{BRITA LUGGENES}

Medisinsk avdeling

Haugesund sjukehus

\section{HALLVARD VINDENES}

Haukeland universitetssykehus

\section{BAKGRUNN .}

Brannskader hos barn kan medføre varige men. I denne studien har vi registrert forekomst, skademekanismer og produkter som årsak til brannskader i Bergen i 2007 og sammenliknet resultatene med tidligere undersøkelser fra 1989 og 1998.

\section{MATERIALE OG METODE.}

Studien inkluderer perioden 1.1. 2007-31.12. 2007. Semistrukturerte spørreskjema ble fylt ut av pasient/pårørende og helsepersonell ved Bergen legevakt, legevaktstasjonene i Fana, Åsane og Loddefjord samt ved Haukeland universitetssykehus. Manglende data ble innsamlet retrospektivt ved journalsøk.

\section{RESULTATER.}

Vi registrerte 142 barn med brannskader. 35\% var gutter under to år. Forekomsten var 6,6 per 1 ooo for barn under fem år og 3,1 per 1 ooo for barn under 15 år, noe som er uendret fra tidligere. Kontakt- og skoldingsskader var vanligst og var forårsaket av ovner, komfyrer og varm mat og drikke. 93\% hadde lettgradig brannskade, $6 \%$ ble innlagt i sykehus, av disse ni hadde fire ikke-vestlig bakgrunn. Nesten $95 \%$ hadde fått avkjølende førstehjelp. 
Barn under to år, særlig gutter, er mest utsatt for brannskader, nå oftere forårsaket av ovner enn tidligere. Forekomsten har vært uendret de siste 20 årene og er på samme nivå som i Trondheim for ti år siden. I Harstad oppnådde man i stor grad å redusere antall brannskader etter innføring av forebyggende tiltak. Dette indikerer at forekomsten av brannskader blant barn forblir uendret og høy når det ikke aktivt interveneres lokalt.

\section{Tabell}

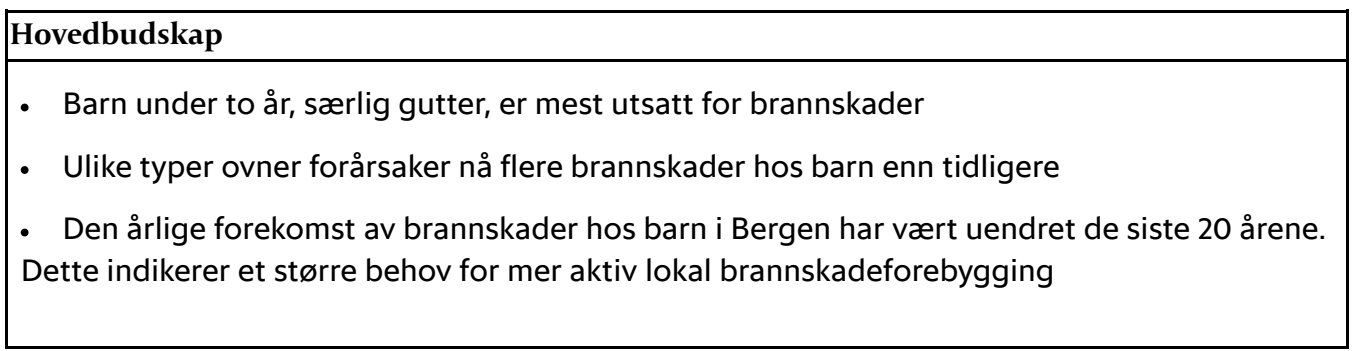

I Norge var det i 2008 flere dødsulykker i brann enn på lenge (11). Heldigvis ble få barn rammet, men på verdensbasis er brannskader den 11. viktigste årsaken til død blant barn i

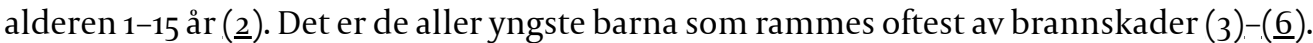
Behandlingen er smertefull, kan være langvarig og er ressurskrevende, og skadene kan medføre varige psykiske, fysiske og funksjonelle men. De fleste brannskader er forutsigbare og kan forebygges med enkle midler. Forebyggende intervensjoner kan effektivt hindre brannskader, noe som er vist i både utenlandske og norske studier (7,, $)$. En Cochraneoversikt fra 2004 etterlyser flere gode studier av effekten av kommunalt baserte, brannskadeforebyggende tiltak (요). Skaderegistrering er imidlertid viktig som utgangspunkt for å finne ut hvor forebyggende tiltak bør settes inn.

I Bergen har vi med niårs intervaller utført epidemiologiske studier av brannskader på barn under 15 år behandlet ved legevakt og på sykehus. Undersøkelsene er gjort i 1989 (3) og 1998 (4). Vi ønsket med en ny studie utført ni år etter den forrige å kartlegge forholdene nå, samt se etter endringer i forekomst, risikogrupper, skademekanismer, produkter som var årsak til brannskaden og bruk av førstehjelp når skaden først var skjedd.

\section{Materiale og metode}

Barn som ikke var fylt 15 år på skadetidspunkt og som var bosatt i Bergen kommune, ble inkludert i studien da de oppsøkte legevakt eller Haukeland universitetssykehus for ny brannskade i tidsperioden 1.1.-31.12. 2007.

Bergen har en barnebefolkning under 15 år på 46333 (per 1.1. 2007) (9). Bergen legevakt er hovedlegevakten i kommunen. Der behandles årlig ca. 100 ooo pasienter. Tre bydelslegevakter er lokalisert i Fana, Åsane og Loddefjord og der behandles årlig ca. 30 ooo pasienter til sammen. Barnebefolkningen er noe overrepresentert som pasienter ved disse vaktstasjonene. Brannskadeavsnittet ved Haukeland universitetssykehus har landsfunksjon for brannskadebehandling og behandler gjennomsnittlig 70 alvorlig brannskadede pasienter per år.

Studien er primært gjennomført som en prospektiv studie, basert på bruk av et semistrukturert spørreskjema (svar som avkryssing, enkeltord, tall eller fritekst) som pasient eller pårørende ble bedt om å fylle ut. Spørreskjemaet inneholdt informasjon om 
barnets alder i antall fylte hele år, skadetidspunkt, skademekanisme og produkt som forårsaket aktuelle brannskade. Det ble videre spurt om førstehjelp var blitt gitt og i så fall hvilken, og om etnisk tilhørighet og fødeland. Det ble ikke spesifikt spurt etter lengde på nedkjølingstiden etter skaden. Sykepleierne som tok imot pasientene ved de ulike behandlingsstedene, informerte om studien og spurte om samtykke til deltakelse etter at legen hadde vurdert og initiert behandling av skaden.

Lege eller sykepleier fylte ut supplerende data om skadeutbredelse og skadedybde basert på vurdering ved første konsultasjon. Behandlende helsepersonell skraverte skadeområdet på en kroppstegning i spørreskjemaet, og skadearealet ble deretter estimert av forfatterne etter beregning av at barnets håndflate representerer $1 \%$ av kroppsoverflaten. Der skjema manglet eller ikke var fullstendig utfylt, baserte forfatterne skadeareal på journalnotater. Disse dataene ble innsamlet retrospektivt. Skadedybde ble kun vurdert ved første konsultasjon, noe som kan være en feilkilde ettersom både lettere og alvorligere skader bedre avsløres ved sårkontroll etter noen dager.

Den prospektive delen av studien ble godkjent av Regional etisk komité Vest (REK Vest), Norsk samfunnsvitenskapelig datatjeneste (NSD) og Personvernombudet for forskning.

I løpet av registreringperioden ble det tydelig at kun om lag 40\% av pasienter som var aktuelle for deltakelse ved Bergen legevakt ble rekruttert til studien. For å kvalitetssikre at man kartla den reelle forekomst av brannskader som ble behandlet ved våre institusjoner, ble opplysninger om de resterende pasientene innhentet ved journalsøk.

Journalopplysninger er også benyttet for å supplere ufullstendig utfylte spørreskjemaer. Tillatelsen for denne delen av studien ble før start gitt som en muntlig anbefaling av Regional etisk komité Vest som oppfattet det som kvalitetssikring. Skriftlig tillatelse ble i etterkant av studien gitt av Helsedirektoratet. Leger med behandlingsansvar ved Bergen legevakt og Brannskadeavsnittet ved Haukeland universitetssykehus innhentet skadedata som forskerne fikk overbrakt i anonym form uten koblingsmuligheter til pasientjournalene. Metoden som ble benyttet var derfor ikke i strid med taushetsplikten. Diagnosekodene S14 i ICPC2 og T20 til 32 og T75 i ICD-10, samt alder under fylte 15 år og bostedskommune Bergen (kode 1201) ble brukt i de primære søkene. Persondata ble anonymisert til alder, kjønn og etnisk bakgrunn. Barn med både fornavn og etternavn av ikke-vestlig opprinnelse ble kategorisert til å ha ikke-vestlig bakgrunn. Anamnese, skadebeskrivelse og behandling ble notert. Artikkelforfatterne registrerte og analyserte disse anonyme dataene i eget statistikkprogram.

SPSS versjon 15 ble benyttet ved dataregistreringen. Khikvadrattest eller Fishers eksakte test ble brukt for å vurdere om det var statistisk signifikante forskjeller mellom gruppene. Insidens av brannskader ble beregnet for befolkningen i Bergen i aktuell alder per 1.1. 2007 og angitt med 95\% konfidensintervall (95\% KI). Statistisk signifikans ble satt til $\mathrm{p}<0,05$.

\section{Resultater}

Vi registrerte 142 barn bosatt i Bergen kommune med brannskader i 2007, dvs. en årlig insidens på 3,1 per 1 ooo barn under 15 år ( $95 \% \mathrm{KI}$ 2,6-3,6). For 52 av disse 142 var spørreskjemaene fullstendig utfylt og signert med henblikk på samtykke (37\%). For de resterende 90 (63\%) var det enten ufullstendig utfylte skjemaopplysninger, ingen opplysninger og et ikke-utfylt skjema fra en pasient som reserverte seg mot deltakelse med personidentifiserbare data.

Legevaktene behandlet 94\% av brannskadene, hvorav Bergen legevakt $78 \%$ og vaktstasjonene $17 \%$. Sykehuset behandlet de resterende $6 \%$ av skadene $(n=9)$. To av disse pasientene ble primært behandlet poliklinisk, ytterligere fire ble poliklinisk behandlet etter ett døgns innleggelse mens tre ble sykehusbehandlet i henholdsvis seks, ni og 50 døgn. 
Barn under to år utgjorde $50 \%(n=71)$ av de brannskadede barna, $78 \%$ var under seks år (fig 1). Gutter utgjorde $56 \%$ av de skadede, og i aldersgruppen under to år var $70 \%$ gutter.

Forekomsten av brannskader blant barn under fem år (6,6 per 1 ooo barn) var større enn $\mathrm{i}$ de eldre aldersgruppene (5-9 år: 1,9 per 1 ooo barn, 10-14 år: o,6 per 1 ooo barn). Åtte av de ni barna som ble innlagt i sykehus var under to år.

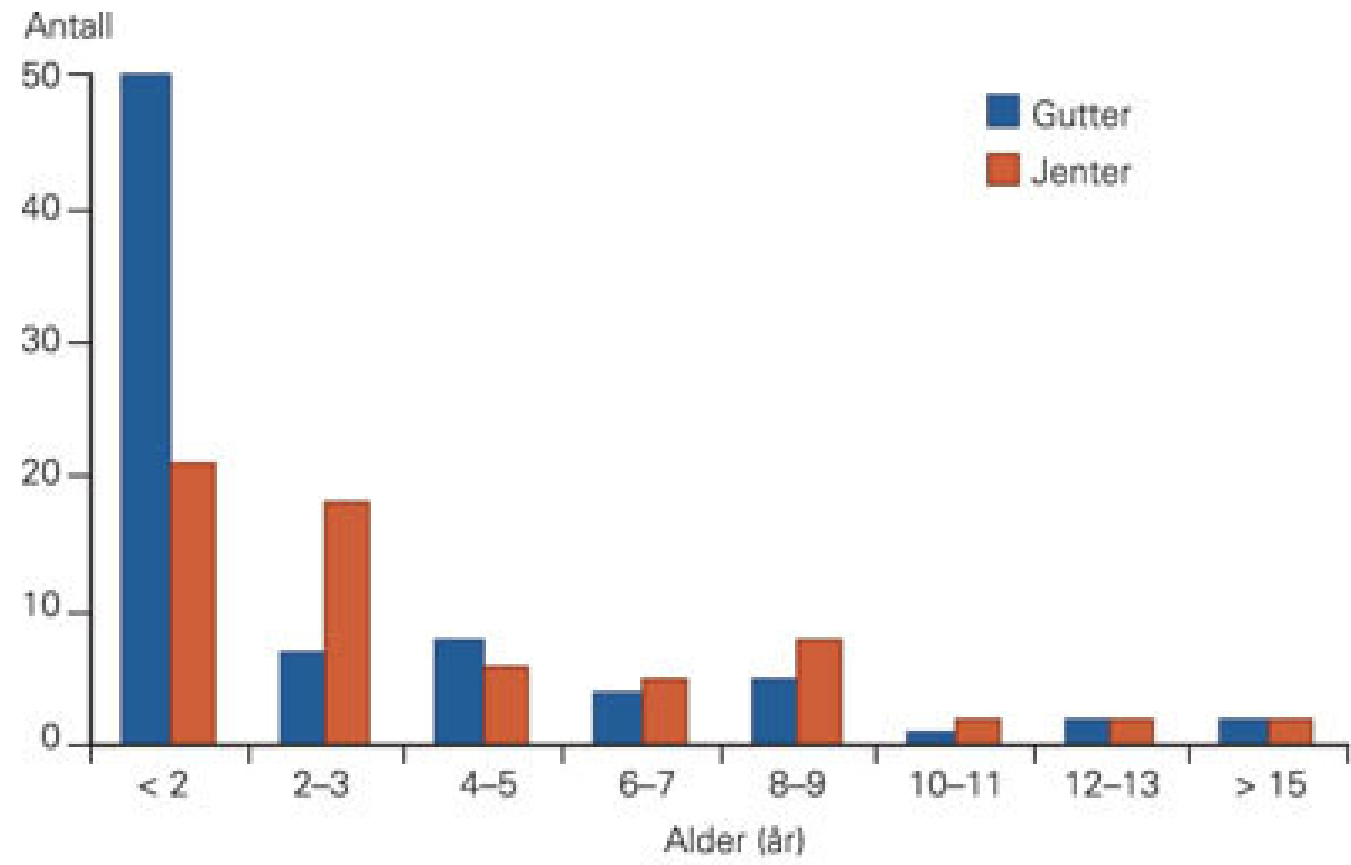

Figur 1 Antall barn behandlet for brannskader i Bergen i 2007 etter kjønn og i ulike aldersgrupper

ETNISITET

Barn med ikke-vestlig bakgrunn utgjorde $10 \%$ av alle brannskadede (14 av 142), og 44\% (fire av ni) av dem som ble behandlet i sykehus. Andelen sykehusinnlagte, brannskadede barn med ikke-vestlig bakgrunn (fire av 14) var signifikant høyere enn andelen blant andre brannskadede barn (fem av 128) (OR 9,84, 95\% KI 1,8-52,9 p = o,oo6).

TIDSPUNKT OG STED

På hverdager forekom nesten halvparten av brannskadene mellom kl 15 og kl 19. I helgene var skadene mer jevnt fordelt utover dagen. $72 \%$ av barna kom til legebehandling innen to timer etter skaden og $88 \%$ kom til lege på samme dag som brannskaden skjedde.

De fleste skadene oppsto innendørs ( $\mathrm{n}=94)$ og da oftest på kjøkkenet $(\mathrm{n}=37)$ eller i stuen $(n=41)$. Kun to skader skjedde på badet. De fleste ble skadet hjemme (68\%), mens kun 6\% skadet seg på skolen eller i barnehagen.

\section{SKADEMEKANISME OG ̊RSAK}

Kontaktskader, oftest forårsaket av ovner (27\%) og komfyrer (18\%) var den vanligste skadetypen, fulgt av skoldingsskader som oftest var forårsaket av varm mat/drikke (33\%) eller andre varme væsker (11\%) (fig 2). Det resterende mindretall av skader skyldtes damp, grill, strykejern, lyspærer, friksjon på kunstgress, rettetang, solforbrenning og stikkontakt $\mathrm{i}$ tillegg til tre flammeskader forårsaket av henholdsvis lighter som antente barnets klær, fyrverkeri/stjerneskudd og stearinlys. 


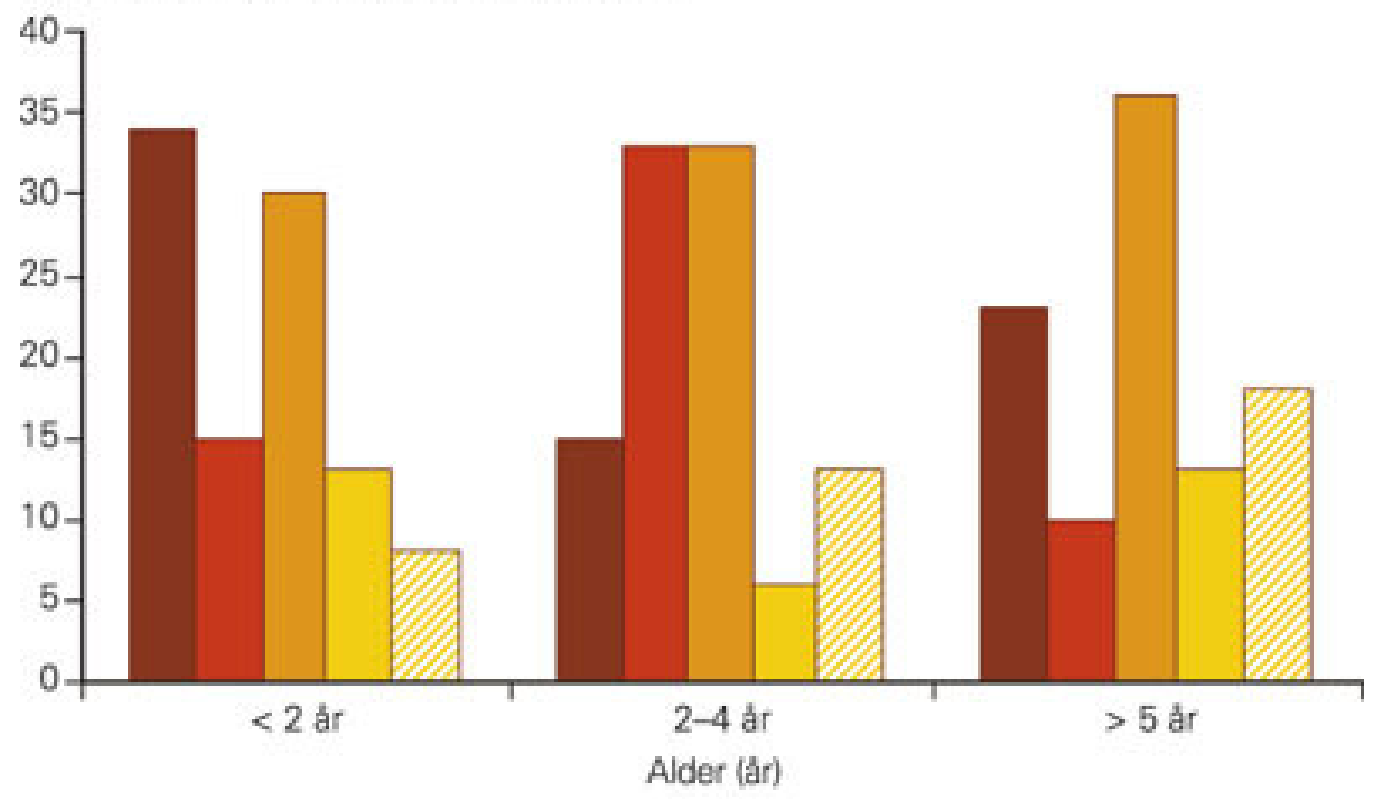

Ovn Komfyr $\square$ Varm mat/drikke $\square$ Annen varm vaske $\square$ Andre ârsaker Figur 2 Ulike skademekanismer ved brannskade hos barn i ulike aldersgrupper, angitt i prosent per aldersgruppe Kontaktskadene rammet oftest hånden og omfattet oftest $\leq 2 \%$ av kroppsoverflaten. Skoldingsskadene fordelte seg over større deler av kroppen og omfattet oftere $>2 \%$ av kroppsoverflaten.

\section{SKADEOMFANG}

Hånden var forbrent i $47 \%$ av skadene, fulgt av skader på bein/sete (13\%), bryst/mage (13\%) og $\operatorname{arm}(9 \%)$. Ti barn fikk brannskader i ansiktet (7\%). De fleste som oppsøkte legevakt for brannskader hadde overflatiske dermale annengradsforbrenninger ( $85 \%$ ). $8 \%$ av skadene var overflatiske førtegradsforbrenninger, mens $6 \%$ var dypere dermal annengradsforbrenning og $1 \%$ var fullhudsskade (tredjegradsforbrenning). De fleste skadene hadde liten utbredelse, 0,25-7\% av kroppsoverflaten. Ingen barn døde av brannskader. I de spørreskjemaene som ble fullstendig utfylt av både pasient/pårørende og helsepersonale $(n=53)$, ble brannskadene vurdert å samsvare med de oppgitte skademekanismer. Det var ingen mistanke om mishandling som skadeårsak.

\section{BEHANDLING}

Under registreringsåret ble det gjort forsøk med bruk av en sølvimpregnert, antimikrobiell, absorberende bandasje (Aquacel AG). Denne ble brukt i 53\% av skadene, mens en mer tradisjonell parafininnsatt salvebandasje (Jelonet) ble brukt i $35 \%$ av tilfellene. På de mindre brannskadene brukte man fuktighetskrem og vaselin, mens det ved sekundærinfiserte brannsår ble benyttet en sølv- og sulfaholdig antibakteriell krem (Flamazine) eller en antibiotikaholdig salve (Fucidin). Ett barn fikk behandling i form av hudtransplantasjon. Hos en av tre ble smertelindrende behandling gitt i forbindelse med skadebehandlingen.

\section{FØRSTEHJELP OG FOREBYGGING}

Hos 106 av 111 pasienter (95\%) var det blitt gitt førstehjelp i form av nedkjøling. I gruppen barn under to år oppga $55 \%$ av foreldrene at skaden kunne vært hindret ved sikringstiltak som ovnssikring, endret plassering av gjenstander, barnegrind, termostat på vannkran og sikring av stikkontakt. I gruppen av eldre barn var denne andelen $18 \%$.

\section{Diskusjon}


Vi fant i denne studien fra 2007 at forekomsten av brannskader var 3,1 per 1 ooo barn under fylte 15 år ( $95 \%$ KI 2,6-3,6). I 1989 (3) og i 1998 (4) ble det utført liknende studier ved Bergen legevakt og Haukeland universitetssykehus der insidenstallene for samme aldersgruppe var på henholdsvis 3,4 (95\% KI 2,8-4,0) og 3,2 per 1 ooo barn (95\% KI 2,7-3,7). Det er tankevekkende at det ikke har skjedd en nedgang i forekomsten av brannskader blant barn i Bergen i løpet av de siste 20 årene. Våre funn støttes også av en sykehusundersøkelse fra Brannskadeavsnittet ved Haukeland universitetssykehus der man ikke så noen reduksjon i antall innlagte brannskadepasienter i løpet av de siste 20 årene (5).

De fleste brannskader rammer de yngste barna (3)-(ㅁ), noe som også bekreftes i internasjonale registreringer $(\underline{2}, \underline{10})-(\underline{12})$. Barn under to år utgjorde nesten halvparten av alle de brannskadede i vår studie, og i denne gruppen var andelen gutter på 70\%. Gutter under to år utgjør dermed en tredel av alle barn med brannskader. At yngre gutter er i overvekt blant brannskadede er også beskrevet tidligere $(3, \underline{4}, \underline{6}, \underline{12})$.

I studien av brannskader i Bergen fra 1998 fant man at seks av 15 sykehusinnlagte hadde ikke-vestlig bakgrunn (4). Vi fant at fire av de ni sykehusinnlagte i vår studie hadde ikkevestlig bakgrunn. Andelen innlagte barn med slik etnisk minoritetsbakgrunn er dermed høyere enn ventet ut fra befolkningssammensetningen i Bergen, der kun 6,6\% hadde ikkevestlig bakgrunn i 2007 (9). Antall sykehusinnlagte barn er heldigvis lavt i vårt materiale, noe som gjør det vanskelig å trekke slutninger om årsaker til denne forskjellen. Indikasjonsterskelen for innleggelse av barn fra etniske minoriteter kan være lavere basert på kommunikasjonsvansker både vedrørende anamnese, behandling og oppfølging.

For de 111 pasientene der det var gitt opplysninger om førstehjelp, var 95\% blitt behandlet med nedkjøling. Dersom ingen av de resterende 31 pasienter i studien, der opplysninger ikke var gitt, hadde fått riktig førstehjelp, ville andelen likevel vært på $75 \%$. Studier fra andre land har vist langt lavere andel førstehjelpsbehandling (무, 12). Vårt forbehold er imidlertid at vi mangler data på om nedkjølingen var adekvat. Vi mangler også informasjon om det forekom eventuell skadelig nedkjøling.

Hånden er vanligste lokalisasjon for brannskader (3,11) også i vår studie (47\%). I 1998 skyldtes $16 \%$ av brannskadene kontakt med ovn, mens denne andelen var på $27 \%$ i 2007. Det kan se ut som om dagens ovner, det være seg både elektriske panelovner, oljeovner og vedovner, ikke er godt nok tilpasset hjem med småbarn. Antall kontaktskader forårsaket av at barna var kommet borti komfyr var uendret i løpet av de siste ni årene (15\% i 1998 og 18\% i 2007).

Over halvparten av foreldrene til de brannskadede barna under to år anga at sikringstiltak kunne hindret skaden. Dette klarte man å bevise i Harstad der man fikk en signifikant nedgang i forekomsten av brannskader hos barn i aldersgruppen under fylte fem år etter en sjuårsperiode med systematiske, forebyggende tiltak (7.). Ved hjelp av omfattende, lokale forebyggende tiltak på ulike nivåer, ble forekomsten av brannskader redusert fra 5,2 til 2,5 per 1 ooo barn i denne aldersgruppen. Trondheim ble brukt som sammenlikningskommune ettersom de ikke hadde noen nye forebyggende intervensjoner, og der steg forekomsten fra 6,2 til 6,8 per 1 ooo barn i samme periode. Våre insidenstall for brannskader på barn under fylte fem år ligger på det samme som i Trondheim, nemlig 6,6 per 1 ooo barn (95\% KI 5,3-7,9). I en studie fra USA fant man i perioden 1993-2004 en nedgang i det totale antall brannskader registrert ved legevakter (11). I den yngste aldersgruppen, under ti år, fant man imidlertid ingen nedgang, og den årlig insidensen var $3,3$ per 1 ooo barn ( $95 \% \mathrm{KI} 2,8-3,7)$. I samme aldersgruppe fant vi en årlig innsidens på 4,o per 1 ooo barn (95\% KI 3,3-4,7).

Bergen kommune ble i 2005 tildelt tittelen trygt lokalsamfunn fra WHO for å ha fokus på skadeforebygging. Vår studie kan indikere at vi ikke har hatt noen reduksjon i forekomsten av brannskader blant barn de siste 20 årene. Vi ligger i dag på nivå med Trondheim for ti år siden, der det heller ikke var introdusert systematiske, lokale, brannskadeforebyggende tiltak. Den skadeforebyggende modellen fra Harstad har vist seg effektiv i et mindre 
lokalsamfunn. Den omfatter både aktive og passive forebyggende tiltak via en kommunal handlingsplan der helsesøstertjenesten spiller en spesielt aktiv rolle (7.). Det hadde vært interessant å se om liknende, lokale intervensjoner av høy kvalitet, kunne ført til en reduksjon i antall brannskader blant barn i Bergen i løpet av den neste niårsperioden.

Studier som denne er ment å være grunnlag for mer målrettede forebyggende intervensjoner. Brannskader forårsaket av kontakt med varme ovner utgjorde en større andel av skadeårsakene enn tidligere. Det var positivt å merke seg den høye andelen skadede som hadde fått førstehjelp i form av avkjøling før legekontakt. Vår studie viste at gutter under to år er særlig utsatt for brannskader, og at barn med ikke-vestlig minoritetsbakgrunn oftere blir innlagt i sykehus. Det bør kanskje rettes særlig oppmerksomhet mot disse risikogruppene.

\section{Oppgitte interessekonflikter:}

Ingen

\section{LITTERATUR}

1. Norsk brannvernforening. Brannstatistikk. www.brannvernforeningen.no/brannstatistikk (5.3.2009).

2. World Health Organization, International Society for Burn Injuries 2006. Facts about injuries: Burns. Genève: WHO, 2006.

3. Hove LM, Lindtjørn B. Epidemiology of burns in Bergen, Norway. Scand J Plast Reconstr Surg Hand Surg 1999; 33: 225-9. [PubMed]

4. Brudvik C. Child injuries in Bergen, Norway. Injury 2000; 31: 761-7. [PubMed] [CrossRef]

5. Onarheim H, Guttormsen AB, Eriksen E. Brannskadebehandling gjennom 20 år ved Haukeland Universitetssykehus. Tidsskr Nor Legeforen 2008; 128: 1168-71. [PubMed]

6. Onarheim H, Vindenes HA. Sykehusopphold for brannskade. Tidsskr Nor Lægeforen 2004; 124: 2130-2. [PubMed]

7. Ytterstad B, Smith GS, Coggan CA. Harstad injury prevention study: prevention of burns in young children by community based intervention. Inj Prev 1998; 4: 176-8o. [PubMed] [CrossRef]

8. Turner C, Spinks A, McClure RJ et al. Community-based interventions for the prevention of burns and scalds in children. Cochrane Database Syst Rev 2004; nr. 3: CDo04335. [PubMed]

9. Statistisk Sentralbyrå. Statistikkbanken. www.ssb.no/tabell/o3o26 (26.2.2009).

10. Rawlins JM, Khan AA, Shenton AF et al. Epidemiology and outcome analysis of 208 children with burns attending an emergency department. Pediatr Emerg Care 2007; 23: 289-93. [PubMed] [CrossRef]

11. Fagenholz PJ, Sheridan RL, Harris NS et al. National study of Emergency Department visits for burn injuries, 1993 to 2004. J Burn Care Res 2007; 28: 681-90. [PubMed] [CrossRef]

12. Tse T, Poon $\mathrm{CH}$, Tse $\mathrm{KH}$ et al. Paediatric burn prevention: an epidemiological approach. Burns 2006; 32: 229-34. [PubMed] [CrossRef]

Publisert: 7. januar 2011. Tidsskr Nor Legeforen. DOI: 10.4045/tidsskr.09.0641

Mottatt 14.5. 2009, første revisjon innsendt 19.9. 2009, godkjent 21.10. 2010. Medisinsk redaktør

Michael Bretthauer.

(C) Tidsskrift for Den norske legeforening 2023. Lastet ned fra tidsskriftet.no 26. april 2023. 